\title{
Efektivitas Pemungutan Retribusi Tempat Rekreasi dan Olahraga Kabupaten Bogor
}

\author{
Indra Sumarna Sobari ${ }^{1 *}$ \\ ${ }^{1}$ Institut Ilmu Sosial dan Manajemen STIAMI, Jakarta, Indonesia \\ 1 indra@stiami.ac.id \\ * corresponding author
}

\section{ARTICLE INFO}

\section{Article history}

Received 2020-02-02

Revised 2020-05-05

Accepted 2020-06-22

Keywords

Retribution, Recreation, Sport Sites

\begin{abstract}
Receipt of retribution from recreation and sports venues in Bogor Regency annually corrects the decline. Therefore, this study aims to analyze the effectiveness of retribution collection on recreational and sports sites. This research is a qualitative study with data collection techniques in the form of interviews, observation and written document. The results of the study indicate that this levy was less effective in 2018. This was caused by poor quality human resources and inadequate infrastructure facilities.
\end{abstract}

\section{PENDAHULUAN}

Pengelolaan retribusi daerah pada pemerintahan daerah Kabupaten Bogor dilaksanakan oleh Badan Pengelolaan Pendapatan Daerah (Bappenda). Pada dasarnya Kabupaten Bogor memiliki potensi retribusi daerah yang cukup besar. Berdasarkan UU No.28 Tahun 2009 jenis retribusi dibagi menjadi 3 golongan yaitu jasa umum, jasa usaha, dan perizinan tertentu . Ada beberapa jenis-jenis dari retribusi jasa usaha yang salah satunya ialah retribusi tempat rekreasi dan olahraga. Retribusi tempat rekreasi dan olahraga adalah retribusi atas pelayanan tempat rekreasi, pariwisata dan olahraga yang disediakan, dimiliki dan/atau dikelola oleh Pemerintah Daerah. Potensi retribusi daerah ini haruslah dikelola dengan sebaik-baiknya untuk peningkatan Pendapatan Asli Daerah Kabupaten Bogor. Berikut target dan realisasi retribusi tempat rekreasi dan olahraga Kabupaten Bogor tahun 2015-2018.

Tabel 1. Target dan Realisasi Retribusi Tempat Rekreasi dan Olahraga Kabupaten Bogor Tahun 2015-2018

\begin{tabular}{|c|c|c|c|}
\hline Tahun & Target & Realisasi & Persentase \\
\hline 2015 & $37.635 .000,00$ & $37.700 .000,00$ & $100,17 \%$ \\
\hline 2016 & $37.925 .000,00$ & $37.925 .000,00$ & $100,00 \%$ \\
\hline 2017 & $40.000 .000,00$ & $32.400 .000,00$ & $81,00 \%$ \\
\hline 2018 & $42.000 .000,00$ & $28.400 .000,00$ & $67,62 \%$ \\
\hline
\end{tabular}

Sumber : Badan Pengelolaan Pendapatan Daerah, data diolah peneliti

Dari tabel diatas, menunjukan bahwa penerimaan tahun 2015 sudah melebihi target yang ditentukan dengan persentase sebesar 100,17\%. Di tahun 2016 mengalami penurunan realisasi namun masih tetap mencapai target dengan persentase sebesar 100,00\%, akan tetapi pada tahun 2017 dan 2018 mengalami penurunan yang cukup signifikan yaitu dengan persentase sebesar 81,00\% dan 67,62\%.

Permasalahan yang dihadapi oleh daerah pada umumnya dalam kaitan penggalian sumber-sumber retribusi tempat rekreasi dan olahraga belum memberikan kontribusi yang signifikan terhadap 
penerimaan daerah secara keseluruhan. Mengingat Kabupaten Bogor memiliki luas sekitar 2.301,95 $\mathrm{km} 2$ atau setara dengan 5,19\% dari luas wilayah Provinsi Jawa Barat. Dibentuk oleh bentang alam yang sangat bervariasi, mulai dari dataran, perbukitan hingga pegunungan sehingga menghasilkan banyaknya objek tempat wisata dan olahraga yang dapat dimanfaatkan yang dapat meningkatkan penerimaan daerah apabila dikelola dengan baik.

Dalam penelitian ini, peneliti merumuskan tiga pertanyaan penelitian yakni: 1) Bagaimana efektivitas pemungutan retribusi tempat rekreasi dan olahraga di Badan Pengelolaan Pendapatan Daerah Kabupaten Bogor tahun 2018? 2) Apa saja hambatan-hambatan yang dihadapi Bappenda Kabupaten Bogor dalam pemungutan retribusi tempat rekreasi dan olahraga?

\section{KAJIAN PUSTAKA}

\section{Retribusi Daerah}

Menurut Mardiasmo (2016:18), yaitu: "Retribusi adalah pungutan daerah sebagai pembayaran atas jasa atau pemberian izin tertentu yang khusus disediakan dan/atau diberikan oleh Pemerintah Daerah untuk kepentingan orang pribadi atau badan". Sedangkan menurut Darwin (Brotodiharjo,1993:7), ialah: "Salah satu sumber penerimaan negara adalah retribusi. Berbeda dengan pajak, retribusi pada umumnya berhubungan dengan kontra prestasi langsung, dalam arti bahwa pembayar retribusi akan menerima imbalan secara langsung dari retribusi yang dibayarnya".

Menurut Darwin (2010:167), terdapat tiga jenis retribusi daerah yaitu:

\section{Retribusi Jasa Umum}

Objek retribusi jasa umum berupa pelayanan yang disediakan maupun diberikan oleh pihak pemerintah daerah untuk tujuan kepentingan dan kemanfaatan umum yang dapat dinikmati baik oleh perseorangan maupun badan.

\section{Retribusi Jasa Usaha}

Objek retribusi jasa usaha adalah pelayanan yang disediakan oleh pemerintah daerah dengan menganut prinsip komersial. Adapun prinsip komersial yang dimaksud berupa pelayanan dengan memanfaatkan kekayaan daerah yang belum dimanfaatkan secara optimal maupun pelayanan oleh pemerintah daerah yang belum disediakan secara memadai oleh pihak swasta

\section{Retribusi Perizinan Tertentu}

Objek retribusi perizinan tertentu berkaitan dengan kegiatan pemanfaatan ruang, penggunaan sumber daya alam barang,sarana dan prasarana serta fasilitas tertentu guna melindungi kepentingan umum serta menjaga kelestarian lingkungan.

Dalam hal ini, retribusi tempat rekreasi dan olahraga merupakan salah satu jenis retribusi jasa usaha yang mana prinsip dan sasaran penetapan tarif retribusi jasa usaha menurut Mardiasmo (2016:21) ialah didasarkan pada tujuan untuk memperoleh keuntungan yang layak, yaitu keuntungan yang diperoleh apabila pelayanan jasa usaha tersebut dilakukan secara efisien dan berorientasi pada harga pasar.

\section{Retribusi Tempat Tempat Rekreasi dan Olahraga}

Menurut Siahaan (2010:632), Retribusi Rekreasi dan Olahraga adalah retribusi atas pelayanan tempat rekreasi, pariwisata dan olahraga yang disediakan, dimiliki dan/atau dikelola oleh Pemerintah Daerah.Adapun objek pajaknya menurut Siahaan (2010:633) ialah pelayanan tempat rekreasi, pariwisata, dan olahraga yang disediakan, dimiliki dan/atau dikelola oleh Pemerintah Daerah.

Dikecualikan dari objek retribusi tempat rekreasi dan olahraga adalah pelayanan tempat rekreasi, pariwisata dan olahraga yang disediakan, dimiliki dan/atau dikelola oleh Pemerintah, BUMN, BUMD, dan pihak swasta. Darwin (2010:172) menyebutkan Subjek retribusi tempat rekreasi dan olahraga adalah orang pribadi atau badan yang memanfaatkan jasa pelayanan tempat rekreasi, pariwisata dan olahraga yang disediakan, dimiliki dan/atau dikelola oleh Pemerintah Daerah. Wajib retribusi tempat rekreasi dan olahraga adalah orang pribadi atau badan yang menurut ketentuan peraturan perundang-undangan 
retribusi diwajibkan untuk melakukan pembayaran retribusi tempat rekreasi dan olahraga, termasuk pemungut atau pemotong retribusi tempat rekreasi dan olahraga.

\section{Efektivitas}

Efektivitas adalah suatu ukuran yang menyatakan seberapa jauh target (kuantitas,kualitas dan waktu) telah tercapai.

Nurlan (Nalle:2017) mengemukakan bahwa pengertian efektivitas pada dasarnya berhubungan dengan pencapaian tujuan datau target kebijakan (hasil guna). Efektivitas merupakan hubungan antara keluaran dengan tujuan atau sasaran yang harus dicapai. Kegiatan operasional dikatakan efektif apabila proses kegiatan mencapai tujuan dan sasaran akhir kebijakan.

\section{Rasio efektivitas $=$ Realisasi retribusi tempat rekreasi dan olahraga $\quad \mathrm{X} 100 \%$ \\ Target retribusi tempat rekreasi dan olahraga}

Pengukuran tingkat efektivitas sebagai berikut:

\section{Pengukuran efektivitas}

\begin{tabular}{|l|l|}
\hline Sangat Efektif & Lebih dari 100\% \\
\hline Efektif & $90 \%-100 \%$ \\
\hline Cukup Efektif & $80 \%-90 \%$ \\
\hline Kurang Efektif & $60 \%-80 \%$ \\
\hline Tidak Efektif & Kurang dari $60 \%$ \\
\hline
\end{tabular}

Sumber : Depdagri, Kepmendagri NO 690.900.327 tahun 1996

Menurut Duncan (Steers:1985:53) mengemukakan tiga (3) indikator yang sangat mempengaruhi terhadap efektivitas, yaitu :

1. Pencapaian Tujuan

Adalah keseluruhan upaya pencapaian tujuan harus dipandang sebagai suatu proses. Oleh karena itu, agar pencapaian tujuan akhir semakin terjamin, diperlukan pentahapan, baik dalam arti pentahapan pencapaian bagian - bagiannya maupun pentahapan dalam arti periodesasi. Pencapaian tujuan sendiri terdiri dari beberapa factor, yaitu : kurun waktu pencapaian ditentukan, Sasaran merupakan target yang kongrit, dasar hukum.

2. Integrasi

Pengukuran terhadap tingkat kemampuan suatu organisasi untuk mengadakan sosialisasi, pengembangan consensus dan komunikasi dengan berbagai macam organisasi lainnya. Integrase terdiri dari beberapa factor, yaitu: prosedur, proses sosialisasi.

\section{Adaptasi}

Proses penyesuaian diri yang dilakukan untuk menyelaraskan suatu individu terhadap perubahan perubahan yang terjadi di lingkungannya. Adaptasi terdiri dari beberapa factor, yaitu : peningkatan kemampuan, sarana dan prasarana . 


\section{METODE PENELITIAN}

Penelitian ini menggunakan pendekatan kualitatif. Adapun Teknik pengumpulan data primer dengan observasi dan in-depth interview dengan beberapa informan yakni Bapak Tedi Supriyadi, S.E, MM selaku Kasubid. Pengendalian dan Evaluasi, Bid. Renbang Bappenda Kabupaten Bogor Bapak Didik Darmadi, S.I.Kom selaku Kepala Seksi Daya Tarik Wisata Bid. Destinasi Pariwisata Disbudpar Kabupaten Bogor dan Wajib Retribusi. Selain itu, peneliti juga menggunakan data sekunder yang berasal dari Bappenda Kabupaten Bogor.Sebagaimana yang diungkapkn Miles \& Huberman (Abas:2017:80), data dalam penelitian ini akan melalui empat tahapan analisis yakni pengumpulan data, reduksi data dan penarikan kesimpulan secara induktif.

\section{HASIL DAN PEMBAHASAN}

\section{Efektivitas Pemungutan Retribusi Tempat Rekreasi dan Olahraga di Badan Pengelolaan Pendapatan Daerah Kabupaten Bogor}

Dalam teori Efektivitas menurut Duncan yang dikutip Richard M. Steers (Steers 1985:53) suatu kebijakan dipengaruhi oleh 3 (tiga) faktor yaitu Pencapaian tujuan, Integrasi dan Adaptasi. Faktor-faktor saling berkaitan satu sama lain dalam proses Pemungutan Retribusi Tempat Rekreasi dan Olahraga di Badan Pengelolaan Pendapatan Daerah Kabupaten Bogor.

\section{Pencapaian Tujuan}

Pencapaian adalah keseluruhan upaya pencapaian tujuan harus dipandang sebagai suatu proses. Oleh karena itu tujuan akhir harus serta merta mempertimbangkan rangkaian kegiatan/ tahapan yang dilaluinya, tidak bisa suatu tujuan akhir dinilai sebagai sesuatu yang absolut/ berdiri sendiri. . Pencapaian tujuan menurut teori ini terdiri dari beberapa faktor, yaitu : (1) Kurun waktu pencapaiannya ditentukan, (2) sasaran merupakan target yang kongkrit, (3) dasar hukum.

Pemungutan retribusi tempat rekreasi dan olahraga pada dasarnya sudah ditentukan target yang harus terealisasi dari tahun sebelumnya, dimana ketentuan tersebut sudah di rapatkan oleh Bidang Rencana dan Evaluasi Bappenda Kabupaten Bogor dan Dinas yang menangani langsung pemungutan retribusi tersebut yaitu Dinas Kebudayaan dan Pariwisata, yang mana di landasi oleh Peraturan Daerah Kabupaten Bogor No. 29 Tahun 2011 Tenang Retribusi Jasa Usaha yang telah di sahkan oleh Bupati Kabupaten Bogor. Didalam PERDA tersebut mencakup semua jenis retribusi jasa usaha termasuk retribusi tempat rekreasi dan olahraga yang terdapat pada BAB VII PERDA ini.

Hal ini sejalan hasil wawancara yaitu tujuan utamanya adalah untuk meningkatkan PAD terkhusus wisata minat khusus karena tidak semua orang berdatangan ketempat tersebut, biasanya dipakai untuk penelitian, kunjungan komunitas pencinta alam dan wisata spiritual, namun tidak menutup kemungkinan siapa saja bisa berkunjung untuk melihat keindahan tempat tersebut. Informasi tersebut menjelaskan bahwa kurun waktu pencapaian pemungutan retribusi tempat rekreasi dan olahraga bertujuan untuk menambah APBD yang sudah di tetapkan dalam undangundang pajak dan retribusi daerah yang mana lebih tepatnya untuk meningkatkan pendapatan Asli Daerah Kabupaten Bogor

Penerimaan retribusi tempat rekreasi dan olahraga kurang efektif, hal tersebut dapat dilihat dari tingkat efektivitas pemungutan retribusi dilihat dari capaian targetnya yang pada tahun 2018 hanya mencapai $67,62 \%$ dari target. Hal tersebut juga disampaikan dalam hasil wawancara bahwa kontribusinya sangat kurang karena objeknya hanya satu, kunjungan wisatawanpun sangat kurang. Informan menjelaskan kalau bicara efektif dan efisien tentu belum, karena angkanya terlalu kecil dan dibandingkan biaya yang dikeluarkan harus dievaluasi lagi. Sedangkan untuk sasaran dalam menentukan target Bappenda mengundang tiap satuan kerja perangkat daerah untuk mengadakan rapat membicarakan masing-masing potensi pajak dan retribusi, potensinya seperti apa, harga tiket dan berapa rata-rata sehari pemasukannya, agar dapat menentukan berapa target yang ditentukan dalam satu tahun anggaran.

Bappenda juga mempunyai tugas pokok yaitu membantu Bupati dalam melaksanakan fungsi penunjang urusan pemerintahan khusunya penunjang bidang pendapatan daerah seperti yang di 
tetapkan di dalam PERBUP No. 70 Tahun 2016 Tentang Kedudukan, Susunan Organisasi, Tugas Dan Fungsi, Serta Tata Kerja Badan Pengelolaan Pendapatan Daerah. Dalam pemungutan retribusi tempat rekreasi dan olahraga Bappenda memiliki peran untuk mengkoordinasi pengendalian dan pengawasan dalam retribusi tersebut. Hal ini dibenarkan oleh informan yaitu tugas Bappenda sebagai koordinator tentu mengacu pada aturan-aturan, pertama tugas Bappeda hanya merekonsiliasi penerimaan dengan bendahara retribusi terkait, kedua melakukan evaluasi dengan mengundang ke Bappenda untuk capai-capaian dan tidak tercapai apa upaya-upaya dinas terkait yang mengelola retribusi tersebut.

Untuk mendapatkan target yang kongkrit perlu dilakukan pemeliharaan secara berkala dan menambah fasilitas, sarana dan prasarana agar lebih nyaman. Penerapan peraturan daerah tentang retribusi daerah khusunya retribusi tempat rekreasi dan olahraga telah dilakukan dengan baik sesuai peraturan yang ada. Menurut informan, kebijakan tentang peraturan daerah sudah diterapkan dengan baik sesuai amanat Bupati. Kegiatan pemungutan retribusi tempat rekreasi dan olahraga mempunyai dasar hukum yaitu UU No. 28 Tahun 2009 Tentang Pajak Daerah dan Retribusi Daerah dan Perda Kabupaten Bogor Nomor 29 Tahun 2011 Tentang Retribusi Jasa Usaha.

Dari pernyataan di atas dapat di analisis bahwa pemerintah daerah memiliki waktu dan sasaran atau target yang jelas, bahkan fiskus sudah memiliki dasar hukum dan kewenangan yang kuat dalam melakukan pemungutan retribusi tempat rekreasi dan olahraga dengan adanya PERDA pemungutan retribusi jasa usaha. Akan tetapi terkadang fiskus tidak menggunakan kewenangannya dengan baik sehingga membuat penerimaan yang dihasilkan dari pemungutan tidak maksimal. Dibutuhkan peran aktif dari fiskus untuk mewujudkan penerimaan retribusi daerah yang optimal dalam penerapannya, karena pengelolaan yang kurang baik dapat mengurangi penerimaan. Kegiatan pemungutan merupakan tindakan aktif fiskus untuk membantu mendongkrak penerimaan dari retribusi daerah.

\section{Integrasi}

Integrasi yaitu pengukuran terhadap tingkat kemampuan suatu organisasi untuk mengadakan sosialisasi, pengembangan konsensus dan komunikasi dengan berbagai macam organisasi lainnya. Integrasi terdiri dari beberapa faktor, yaitu : prosedur dan proses sosialisasi.

Integrasi dalam proses pemungutan mencakup prosedur penerimaan retribusi tempat rekreasi dan olahraga, berdasarkan wawancara dengan informan, beliau menjelaskan sedikit tentang prosedur penerimaan retribusi ini yaitu tiket/Karcis dikeluarkan oleh Disbudpar lalu di porporasi agar legal di Bappenda setelah itu dikembalikan ke Disbudpar setelah itu Disbudpar menyerahkan ke kolektor/petugas lapangan. Tiket yang terjual uangnya akan dimasukan ke kas daerah.

Prosedur penerimaan tersebut tidak serta-merta bebas dari para pelanggar kebijakan dalam hal ini petugas lapangan yang belum mengoptimalisasi pemungutan tersebut, untuk itu pihak Disbudpar seperti yang disampaikan informan yaitu langkah tegas yang diambil jika petugas melakukan pelanggaran adalah pertama akan dipanggil pihak Disbudpar untuk diberi teguran lisan jika tidak diindahkan akan diberikan teguran secara tertulis. Dalam melakukan pemungutan pihak Disbudpar melakukan sosialisasi yang berbentuk pembinaan yang dilakukan oleh petugas kantor Dinas Kebudayaan dan Pariwisata seksi Daya Tarik Wisata ke petugas-petugas lapangan di kawasan objek wisata. Dari hasil wawancara dengan informan dapat di simpulkan bahwa pembinaan yang dilakukan bukan semata-mata kepada wajib retribusi langsung tetapi dengan petugas di lapangan untuk mengoptimalisasi pemungutan. Wajib retribusi yang penulis wawancarai juga mengatakan tidak tahu tentang adanya sosialisasi tersebut.

Pembinaan yang dilakukan kepada petugas lapangan dilakukan secara berkala dan berkesinambungan hal tersebut bertujuan agar pemungutan berjalan dengan lancar, meningkatkan pelayanan pemungutan kepada wajib retribusi, dan pemungutan dapat terealiasi sesuai target yang telah di tetapkan. Pembinaan ini dilakukan kurang lebih 20 kali dalam setahun. Selain hal tersebut, sosialisasi/pembinaan yang dilakukan Disbudpar dalam sebulan bisa 2x kunjungan dan biasanya sekali kunjungan bisa 2-3 lokasi objek wisata. 
Integrasi antar department harus terjalanin dan diterapkan antara pemungut retribusi dan pengelola retribusi, di harapkan dengan komunikasi yang baik dapat meningkatkan semangat bekerja dalam melaksanakan pemungutan retribusi dan penerimaan menjadi maksimal, hal tersebut juga diungkap bahwa komunikasi dalam lingkungan Pemda sangat utama karena apa yang tersampaikan atau tidak berasal dari komunikasi, kalau sudah terjalin baik maka koordinasi dalam penerimaan akan mudah, bendahara datang langsung untuk merekon di bank untuk menyamakan angka dan komunikasi lewat data. Komunikasi tersebut terjalin cukup baik karena Petugas lapangan datang langsung sebulan sekali ke Disbudpar untuk melaporkan jumlah tiket yang terjual.

Dan dari hasil wawancara yang peneliti dapatkan, alur penerimaan retribusi ini telah terintegrasi dengan department-department lain di Bappenda hal tersebut karena Bappenda ingin menciptakan transparasi dalam bekerja untuk mewujudkan visi dan misinya.

3. Adaptasi

Adaptasi adalah proses penyesuaian diri yang dilakukan untuk meyelaraskan suatu individu terhadap perubahan-perubahan yang terjadi di lingkungannya. Adaptasi terdiri dari beberapa faktor, yaitu : (1) peningkatan kemampuan (2) sarana dan prasarana.

Dari hasil wawancara peneliti dengan informan, diketahui bahwa SDM yang ada di Bidang Renbang dan Bappenda meliputi 3 Kasubid dan total dengan staff pns dan rekrutment menjadi 32 orang, di Bidang Renbang ada 2 orang yang SMA dan lainnya sarjana, untuk jumlah keseluruhan pegawai Bappenda ada 440 orang dengan tingkat pendidikan terendah SMP untuk 2 oran tenaga honorer yang mau pensiun, Kebanyakan lainnya sarjana".Diketahui bahwa SDM yang ada di Seksi Daya Tarik Wisata Disbudpar adalah Petugas yang menangani retribusi tempat rekreasi dan olahraga di Disbudpar Kab. Bogor ada 7 orang terdiri dari 1 Kepala seksi, 4 pelaksana dan 2 petugas lapangan. Pendidikannya yaitu 4 orang Sarjana, 2 orang SMA dan 1 orang petugas lapangan/kebersihan SD".

Sumber Daya Manusia yang direkrut oleh Pemerintah Daerah Kabupaten Bogor harus memiliki kompetensi yang sesuai dengan kebutuhan. Pemerintah Kabupaten Bogor menugaskan pegawai untuk bekerja secara profesional, dalam melaksanakan pengelolaan dan pemungutan retribusi tempat rekreasi dan olahraga. Adapun syarat-syarat yang harus dipenuhi untuk menjadi pegawai dilingkungan Bappenda dan Disbudpar adalah sebagai berikut:

a. Untuk PNS berijazah serendah-rendahnya Strata 1/S1;

b. Untuk Honorer berijazah serendah-rendahnya Sekolah Menengah Umum atau setingkat;

c. Untuk honorer yang berijazah serendah-rendahnya Sekolah Menengah Pertama, perekrutan terjadi sudah lama sekali dan pegawai tersebut sudah mau pensiun;

d. Untuk petugas kebersihan di lokasi objek wisata berijazah serendah-rendahnya Sekolah Dasar.

Namun walaupun SDM yang direkrut sudah sesuai kebutuhan dan diharapkan dapat bekerja profesional dalam mengoptimalkan penerimaan tetapi nyatanya penerimaan yang di harapkan belum tercapai. Bedasarkan hasil wawancara dengan informan tentang kinerja petugas pemungutan harus diukur dari ukuran-ukuran nilai, dan dilihat dari target belum tercapai dianggap kurang bagus. Berdasarkan wawancara dengan wajib retribusi, peneliti mendapati bahwa petugas pemungut kurang teratur, kadang karcis masuk tidak diperiksa satu persatu, padahal wajib retribusi sudah membeli 10 tetapi hendak memasuki pintu masuk tidak diperiksa dan langsung dipersilahkan masuk .

Salah satu penyebab tidak tercapainya penerimaan karena sarana prasarana yang dinilai kurang bagus maka dari itu untuk meningkatkan penerimaan diperlukan fasilitas sarana dan prasarana yang menunjang kenyamanan dan keamanan pengunjung, seperti : tempat ibadah, toilet, kantin dan alatalat keamanan lainnya. Sarana dan Prasarana merupakan hal yang sangat penting untuk menunjang efektivitas pemungutan. Karena dengan sarana dan prasarana yang memadaika dapat membuat penerimaan bertambah. Dan sebaliknya kekurangan sarana dan prasarana dapat menyebabkan penerimaan berkurang karena tidak adanya minat dari wajib retribusi untuk berkunjung. Selain sarana dan prasarana yang menunjang, diperlukan strategi untuk meningkatkan penerimaan. Yaitu dengan membuat atraksi wisata lain seperti outbound dan kolam renang dengan pengadaan lahan.

Meningkatkan sarana dan prasarana serta memberikan strategi untuk meningkatkan penerimaan adalah upaya yang akan dilakukan Pemerintah Kabupaten Bogor khususnya 
dilingkungan Badan Pengelolaan Pendapatan Daerah dan Dinas Kebudayaan dan Pariwisata, namun selain hal tersebut diatas untuk mengoptimalkan pemungutan diperlukan pengawasan yaitu Pemerintah daerah seharusnya melakukan kunjungan secara berkala ke dinas terkait dan petugas lapangan untuk melihat kinerja mereka, dan kalau jumlah nilai uang dalam penerimaan bisa dengan menghitung jumlah karcis terjual dan yang tersisa setelahnya merekon dengan jumlah uang yang disetorkan. Hal tersebut juga sejalan dengan yang di sampaikan oleh informan 1 bahwa pengawasan yang dilakukan dengan merekonsiliasi data setiap bulan dengan bendahara di Dinas Kebudayaan dan Pariwisata.

\section{Saran}

1. Pengembangan objek dan daya tarik wisata, melalui pengembangan sarana dan prasarana, dan pengembangan kemampuan pegawai sebagai pelaksana pengembangan pariwisata.

2. Meningkatkan pemasaran dengan melakukan promosi yang seluas-luasnya, baik lewat media cetak maupun internet, serta mengemas produk wisata semenarik mungkin, agar mampu menarik wisatawan untuk datang berwisata di Goa Gudawang.

3. Menambah jumlah pengawas untuk melakukan pengawasan secara berkala dalam hal proses pemungutan dan pengelolaan objek wisata, mengingat realisasi dari tahun 2015 - 2018 terus mengalami penurunan dan tidak mencapai target. Dengan upaya dan saran yang disampaikan diharapkan di tahun berikutnya penerimaan terus mencapai target bahkan dapat meningkat lagi.

\section{DAFTAR PUSTAKA}

Brotodihardjo, R.Santoso. 1995. Pengantar Ilmu Hukum Pajak. Bandung: Eresco

Darwin. 2010. Pajak daerah dan Retribusi Daerah. Jakarta: Mitra Wacana Media

Mardiasmo. 2016. Perpajakan Edisi Terbaru 2016. Yogyakarta: Andi

Siahaan, Mariot P. (2010). Pajak Daerah Dan Retribusi Daerah. Yogyakarta: Fajar Interpratama Mandiri

Steers, Richard M, Terj: Magdalena Jamin. (1985). Efektivitas Organisasi. Jakarta: Erlangga

Undang-Undang Nomor 28 Tahun 2009 Tentang Pajak Daerah Dan Retribusi Daerah.

Peraturan Pemerintah Republik Indonesia Nomor 58 Tahun 2005 Tentang Pengelolaan Keuangan Daerah.

Peraturan Pemerintah Republik Indonesia Nomor 66 Tahun 2001 tentang Retribusi Daerah.

Peraturan Bupati Nomor 70 Tahun 2016 Tentang Kedudukan, Susunan Organisasi, Tugas Dan Fungsi, Serta Tata Kerja Badan Pengelolaan Pendapatan Daerah

Peraturan Daerah Kabupaten Bogor Nomor 29 Tahun 2011 Tentang Retribusi Jasa Usaha.

Peraturan Daerah Kabupaten Bogor Nomor 1 Tahun 2008 Tentang Perubahan atas Peraturan Daerah Kabupaten Bogor Nomor 6 Tahun 1999 Tentang Retribusi Tempat Rekreasi dan Olahraga. 